\title{
Exogenous Administration of Gangliosides Displaces GPI-anchored Proteins from Lipid Microdomains in Living Cells
}

\author{
Mikael Simons, ${ }^{*+}$ Tim Friedrichson, ${ }^{+\ddagger}$ Jörg B. Schulz, ${ }^{*}$ Marina Pitto, $\$$ \\ Massimo Masserini, $\$$ and Teymuras V. Kurzchalia ${ }^{\ddagger \mathbb{I I}}$
}

\begin{abstract}
*Department of Neurology, University of Tübingen, D-77076 Tübingen, Germany; \$Department of Medical Chemistry and Biochemistry, University of Milan, 20133 Milan, Italy; ${ }^{\mathbb{T}}$ Max Planck Institute for Molecular Cell Biology and Genetics, Dresden, Germany; and ‡Department of Cell Biology, MaxDelbrück Centre for Molecular Medicine, D-13092 Berlin-Buch, Germany
\end{abstract}

Submitted November 2, 1998; Accepted July 19, 1999

Monitoring Editor: W. James Nelson

\begin{abstract}
Exogenous application of gangliosides to cells affects many cellular functions. We asked whether these effects could be attributed to the influence of gangliosides on the properties of sphingolipidcholesterol microdomains on the plasma membrane, also termed rafts. The latter are envisaged as lateral assemblies of sphingolipids (including gangliosides), cholesterol, and a specific set of proteins. Rafts have been implicated in processes such as membrane trafficking, signal transduction, and cell adhesion. Recently, using a chemical cross-linking approach with Madin-Darby canine kidney (MDCK) cells permanently expressing a GPI-anchored form of growth hormone decay accelerating factor (GH-DAF) as a model system, we could show that GPI-anchored proteins are clustered in rafts in living cells. Moreover, this clustering was dependent on the level of cholesterol in the cell. Here we show that incubation of MDCK cells with gangliosides abolished subsequent chemical cross-linking of GH-DAF. Furthermore, insertion of gangliosides into the plasma membrane of MDCK GH-DAF cells renders GH-DAF soluble when subjected to extraction with Triton $\mathrm{X}-114$ at $4^{\circ} \mathrm{C}$. Our data suggest that exogenous application of gangliosides displaces GPI-anchored proteins from sphingolipid-cholesterol microdomains in living cells.
\end{abstract}

\section{INTRODUCTION}

Exogenously added gangliosides affect various biological systems. They lead to increased cell adhesiveness, inhibit cell growth, promote cell differentiation, and induce neuritogenesis (Hakomori and Igarashi, 1995). Furthermore, ganglioside treatment is neuroprotective in many in vivo and in vitro models of neuroinjury (Hadjiconstantinou and Neff, 1998). For example, experimental Parkinsonism is partially reversed by ganglioside treatment. Both, $\mathrm{GM}_{1}$ and a lysoderivative of $\mathrm{GM}_{1}$ given after cortical thrombosis reduce infarct size and associate cognitive deficits (Schneider et al., 1992; Kharlamov et al., 1994). Several clinical trials have supported application of gangliosides for treating neurological disease (Geisler et al., 1991; Lenzi et al., 1994). Despite the large number of observed effects, the molecular mechanisms involved in ganglioside action are poorly understood. There is evidence that application of gangliosides alters many

\footnotetext{
${ }^{+}$These authors contributed equally to this work.

| Corresponding author. E-mail address: kurzchal@orion.rz.mdcberlin.de.
}

phosphorylation systems (Hakomori and Igarashi, 1995). Signaling pathways initiated by receptor-associated tyrosine kinases or mediated by protein kinase C, MAP kinase, and other kinases are affected by gangliosides (Hakomori and Igarashi, 1995).

The wide spectrum of biological effects exerted by gangliosides could be explained by interaction of gangliosides with signaling molecules or by influence of the overall structure of plasma membrane, in particular on the formation of cholesterol-sphingolipid rafts. The latter are envisaged as lateral assemblies of specific lipids and proteins in cellular membranes proposed to function in processes such as membrane transport, signal transduction, and cell adhesion (Simons and Ikonen, 1997). They are thought to be small and highly dynamic structures, which explains the difficulties in resolving them using conventional microscopical techniques. Attractive forces between sphingolipids and cholesterol have been postulated to be responsible for the formation of the lateral lipid assembly. Several proteins have been suggested to associate with rafts, including GPI-anchored proteins (GPI-APs), Src-family kinases, influenza virus hemagglutinin (HA), and caveolin-1 (Simons and Ikonen, 1997). 
An interesting feature of raft-associated proteins is that most of them carry posttranslational lipid modifications: GPIanchored proteins are anchored in the cell membrane via a lipid moiety, whereas Src-family kinases, NO synthase, HA, and caveolin are acylated. The lipophilic character of raft proteins may explain their common behavior of poor solubility in cold nonionic detergents such as Triton X-100 (Simons and Ikonen, 1997). Triton insoluble complexes have been operationally defined as rafts that are specifically enriched in certain lipids (e.g., sphingolipids, including gangliosides and cholesterol), whereas other lipids (e.g., glycerophospholipids) are selectively depleted from the extracts (Brown and Rose, 1992; Fiedler et al., 1993); however, the existence of rafts in living cells remained elusive. Recently it was possible to demonstrate the existence of cholesteroldependent microdomains of GPI-anchored proteins in living cells by a chemical cross-linking approach (Friedrichson and Kurzchalia, 1998) and by a novel fluorescent energy-transfer method (Varma and Mayor, 1998). In this article we used our cross-linking approach to investigate how the exogenous application of gangliosides affects rafts in living cells.

\section{MATERIALS AND METHODS}

\section{Cell Culture}

Madin-Darby canine kidney (MDCK) growth hormone decay accelerating factor (GH-DAF) cells were maintained at $37^{\circ} \mathrm{C}$ in $5 \% \mathrm{CO}_{2}$ in DMEM supplemented with $10 \%$ FCS and antibiotics. Chinese hamster ovary (CHO) GPI-anchored folate receptor (FR-GPI) cells were grown in folate-free Ham's F-12 medium containing 5\% FCS, hygromycin $(100 \mu \mathrm{g} / \mathrm{ml})$, penicillin $(100 \mathrm{U} / \mathrm{ml})$, and streptomycin $(100$ $\mu \mathrm{g} / \mathrm{ml})$. Experiments were performed on confluent or subconfluent cells grown in plastic dishes or on coverslips for immunofluorescence labeling.

\section{Insertion of Lipids, Cholesterol Depletion, and Octylglucoside Treatment of Cells}

Stock solutions of bovine brain gangliosides (bbGs) or $\mathrm{GM}_{1}(1-10 \mathrm{mM})$ were prepared in PBS. Cells were loaded with 10-100 $\mu \mathrm{M}$ gangliosides in DMEM for $1 \mathrm{~h}$ at $37^{\circ} \mathrm{C}$ (Masserini et al., 1990; Saqr et al., 1993). To remove excess lipid, cells were washed extensively with PBS containing $2 \mathrm{mg} / \mathrm{ml}$ defatted BSA (PBS/BSA). A $0.5 \%$ ethanolic stock solution of 2-(6-(7-nitrobenz-2-oxa-1,3-diazol-4-yl)amino)hexanoyl-1-hexadecanoyl-sn-glycero-3-phosphocholine (NBD-C 6 - HPC) was injected under vigorous vortexing into PBS to yield a 1-mM solution. Insertion of NBD- $\mathrm{C}_{6}$-HPC into membranes was performed with 10-100 $\mu \mathrm{M}$ NBD$\mathrm{C}_{6}-\mathrm{HPC}$ for $1 \mathrm{~h}$ at $8^{\circ} \mathrm{C}$. To deplete MDCK GH-DAF cells of cholesterol, they were incubated for $1 \mathrm{~h}$ at $37^{\circ} \mathrm{C}$ with $10 \mathrm{mM}$ methyl- $\beta$-cyclodextrin (CD). For octylglucoside treatment, MDCK GH-DAF cells were incubated for $1 \mathrm{~h}$ at $37^{\circ} \mathrm{C}$ with various concentrations of octylglucoside dissolved in DMEM.

\section{Quantification of Ganglioside Association}

$\mathrm{GM}_{1}$ was extracted, purified (Tettamanti et al., 1973), and radiolabeled at C-3 of the long-chain base moiety (Sonnino et al., 1984). The homogeneity of the radioactive compound ${ }^{3} \mathrm{H}-\mathrm{GM}_{1}$ was $>99 \%$, and its specific radioactivity was $1.31 \mathrm{Ci} / \mathrm{mmol}$. Cells were incubated for $1 \mathrm{~h}$ in DMEM containing $1 \mu \mathrm{Ci} / \mathrm{ml}$ tritiated $\mathrm{GM}_{1}$ (final ganglioside concentration $100 \mu \mathrm{M}$ ), washed with PBS/BSA, and subsequently incubated for $0-45 \mathrm{~min}$ with $\mathrm{PBS} / \mathrm{BSA}$ at $37^{\circ} \mathrm{C}$. Cells were then treated for $5 \mathrm{~min}$ at $37^{\circ} \mathrm{C}$ with $1 \mathrm{ml}$ PBS containing $0.1 \%$ trypsin. Cell lysates were analyzed for radioactive ganglioside content with a liquid scintillation counter (Beckmann Instruments, Fullerton, CA).
Protein was determined using a Protein Assay Reagent (BCA; Pierce, Rockford, IL).

\section{Detergent Extraction}

Cells were washed with cold PBS and extracted with $1 \mathrm{ml}$ TX-114 lysis buffer at $4^{\circ} \mathrm{C}$ for $30 \mathrm{~min}$. Cells were scraped, and samples were centrifuged for $30 \mathrm{~min}$ at $15,000 \times \mathrm{g}$ at $4^{\circ} \mathrm{C}$. The supernatant (soluble fraction) was removed, and the pellet (insoluble fraction) was resuspended in $1 \mathrm{ml}$ lysis buffer. Soluble and insoluble fractions were precipitated with $10 \%$ TCA for $1 \mathrm{~h}$ on ice and centrifuged for $15 \mathrm{~min}$ at $15,000 \times g$ at $4^{\circ} \mathrm{C}$. The pellets were washed with acetone $\left(-20^{\circ} \mathrm{C}\right)$ and subjected to SDS-PAGE and Western blotting.

\section{Cross-linking, Electrophoresis, and Western Blotting}

The cross-linking protocol has been described recently (Friedrichson and Kurzchalia, 1998). Briefly, cells were washed twice with cold PBS. Cross-linking was performed with $0.5 \mathrm{mM}$ bis(sulfosuccinimidyl)suberate $\left(\mathrm{BS}^{3}\right)$ for $45 \mathrm{~min}$ at $4^{\circ} \mathrm{C}$. Unreacted cross-linker was quenched with $50 \mathrm{mM}$ glycine for $15 \mathrm{~min}$ at $4^{\circ} \mathrm{C}$. Cells were lysed for $20 \mathrm{~min}$ at $4^{\circ} \mathrm{C}$ and $10 \mathrm{~min}$ at $37^{\circ} \mathrm{C}$ in TX-114 lysis buffer $(150 \mathrm{mM}$ $\mathrm{NaCl}, 10 \mathrm{mM}$ Tris-HCl, pH 8.0, 1 mM EDTA, 1\% Triton X-114, and protease inhibitors). Lysates were briefly chilled on ice and cleared by a 15 min centrifugation at $15,000 \times g$. Supernatants were subjected to temperature-induced phase separation for $5 \mathrm{~min}$ at $37^{\circ} \mathrm{C}$. Aqueous and detergent-enriched phases were separated by a 3-min centrifugation at $13,000 \mathrm{rpm}$ at room temperature (RT). Aqueous phases were discarded, and $0.9 \mathrm{ml}$ TX-114 wash buffer $(150 \mathrm{mM}$ $\mathrm{NaCl}, 10 \mathrm{mM}$ Tris-HCl, pH 8.0, 1 mM EDTA, 0.06\% Triton X-114, and protease inhibitors) was added to detergent phases. After a 15 min centrifugation at $15,000 \times g$ at $4^{\circ} \mathrm{C}$, the samples were subjected to another round of phase separation. Finally, detergent phases were precipitated with cold acetone $\left(-20^{\circ} \mathrm{C}\right)$ and boiled at $95^{\circ} \mathrm{C}$ for $5 \mathrm{~min}$ in Laemmli sample buffer. Proteins were resolved on a $5-15 \%$ SDS-PAGE and transferred to nitrocellulose. Polyclonal antibodies against GH and FR followed by the respective secondary antibodies and ECL were used to detect GH-DAF and FR-GPI. Immunoreactive bands were quantified by densitometric scanning of films or luminescent image analyzer LAS-1000 (Fujifilm, Straubenhardt, Germany). Data for each condition were averaged, and the variability was expressed as SD. Experiments were performed three to six times. For some gels, corresponding $\mathrm{x}$-ray films were scanned using Photoshop software, and optical density of immunoreactive bands was determined and plotted using MacBas (version 2.0).

\section{Immunofluorescence}

Cells grown on coverslips were washed three times with PBS and fixed for 6 min with $3.7 \%$ paraformaldehyde in PBS at $8^{\circ} \mathrm{C}$ and for 10 min with methanol at $-20^{\circ} \mathrm{C}$. Subsequently, the cells were incubated for $30 \mathrm{~min}$ at RT with anti-GH antibody in PBS, followed by incubation with Cy3-conjugated anti-sheep IgG for $30 \mathrm{~min}$ at RT. Each of the above incubations was followed by three washes with PBS. The coverslips were mounted with mowiol, and images were captured with a high-resolution digital camera C 4742-95 (Hamamatsu Photonics K.K., Hamamatsu, Japan), and digital deconvolution was performed using the Openlab (version 1.7.7) digital confocal routine (Coventry, United Kingdom).

For antibody-induced cross-linking experiments of GH-DAF, anti-GH antibody and Cy3-conjugated anti-sheep $\operatorname{IgG}$ were diluted in DMEM. Cells were incubated for $20 \mathrm{~min}$ at $37^{\circ} \mathrm{C}$ with anti-GH antibody, washed with DMEM, and incubated for $20 \mathrm{~min}$ at $37^{\circ} \mathrm{C}$ with Cy3-conjugated anti-sheep IgG. Cells were fixed and mounted as described above.

\section{Viral Infection and Antibody-induced Patching}

For infection with $\mathrm{HA}$ influenza virus, virus was diluted in infection medium (MEM, $50 \mathrm{mM}$ HEPES, pH 7.3, penicillin [100 U/ml]/ 
A
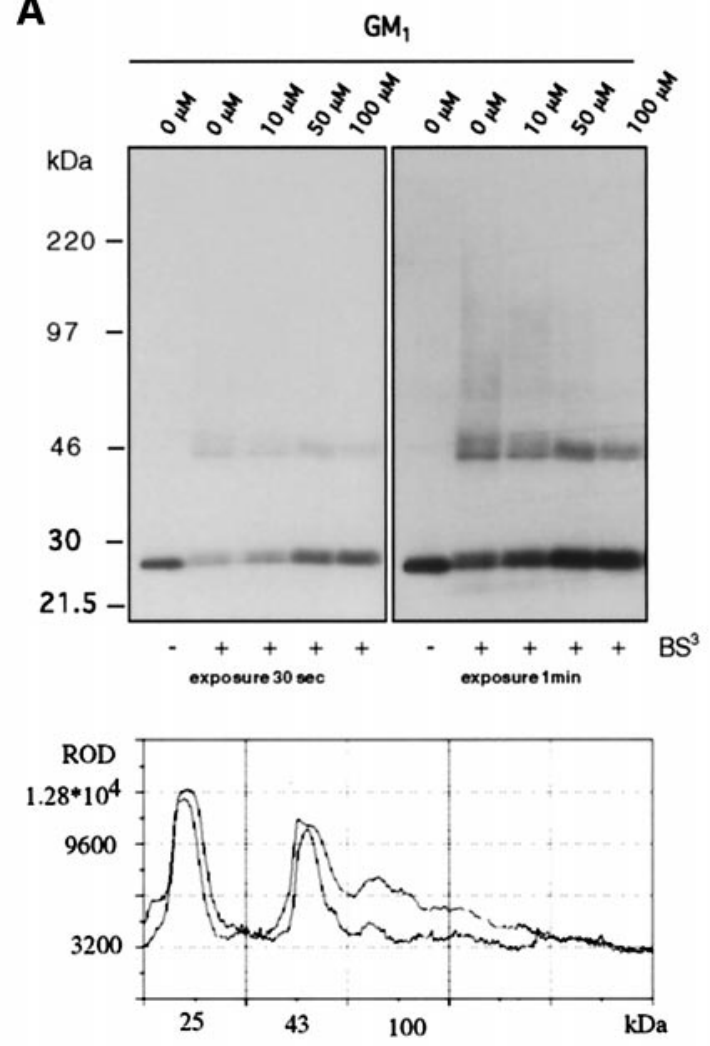

B

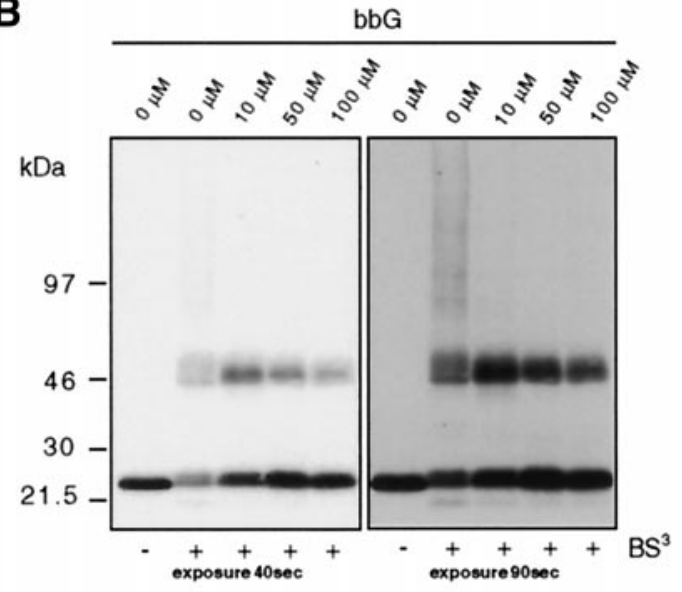

streptomycin [100 $\mu \mathrm{g} / \mathrm{ml}], 0.2 \%$ BSA), and virus adsorption was performed for $1 \mathrm{~h}$. Infection was allowed to continue for a further $2.5 \mathrm{~h} ; 100 \mu \mathrm{M} \mathrm{GM}$ diluted in DMEM was added to some cells during the last hour. For antibody-induced patching of HA and GH-DAF, cells were incubated with polyclonal anti-GH antibody and monoclonal anti-HA-PR8 (H17L10) diluted 1:3000 and 1:50 in DMEM, respectively. Incubation was performed for $1 \mathrm{~h}$ at $4^{\circ} \mathrm{C}$. After they were washed briefly with PBS/0.2\%BSA, cells were incubated with the respective FITC and Cy-3-coupled secondary antibodies for $1 \mathrm{~h}$ at $4^{\circ} \mathrm{C}$. Cells were fixed and mounted, and images were taken as described above. For quantification, 60 randomly selected cells out of two different experiments were stored as digital images. Cells were divided into three different categories according to the degree of overlap between patches: 1 ) coclustering ( $>70 \%$ overlap); 2 ) partial coclustering; and 3) random distribution.

\section{RESULTS}

\section{Inhibition of Cross-linking of GPI-anchored Proteins by Exogenous Administration of Gangliosides}

Our model for analysis of the organization of GPI-anchored proteins on the surface is a MDCK cell line permanently expressing GH fused to the GPI-anchor of DAF (GH-DAF) (Friedrichson and Kurzchalia, 1998). When MDCK GH-DAF cells were subjected to chemical cross-linking with $\mathrm{BS}^{3}$, a prominent $46-\mathrm{kDa}$ band (dimer) and a smear starting from $60 \mathrm{kDa}$ reaching up to $300 \mathrm{kDa}$ were detected by Western blotting (Figure 1A). To investigate the influence of gangliosides on rafts, MDCK GH-DAF cells were loaded with varying concentrations of $\mathrm{GM}_{1}$ for $1 \mathrm{~h}$ in serum-free medium at $37^{\circ} \mathrm{C}$ and subjected to cross-linking with $\mathrm{BS}^{3}$. As seen in Figure $1 \mathrm{~A}$, treatment of MDCK GH-DAF cells with $\mathrm{GM}_{1}$ reduced significantly the amount of cross-linked GH-DAF. Quantification of immunoreactive bands revealed that $73 \pm$ $6 \%$ of GH-DAF formed oligomers in untreated cells, whereas $65 \pm 7,57 \pm 7$, and $49 \pm 7 \%$ of GH-DAF were found in cross-linked species in cells treated with 10, 50, and 100 $\mu \mathrm{M} \mathrm{GM}_{1}$, respectively. Incubation of cells with bbGs also efficiently inhibited the formation of GH-DAF oligomeres (Figure 1B [for $100 \mu \mathrm{M}$ bbG cross-linking efficiency was $51 \pm$ $5 \%$ compared with $73 \pm 6 \%$ in untreated cells]). To determine whether the ability of gangliosides to resolve GPI-APcontaining rafts is independent of the cell type, $\mathrm{CHO}$ cells permanently expressing FR-GPI were subjected to the same treatments. Cross-linking of CHO FR-GPI cells with BS ${ }^{3}$ led to the appearance of cross-linked products of FR-GPI (crosslinking efficiency $28 \pm 3 \%$ ). When CHO FR-GPI cells were loaded with $100 \mu \mathrm{M} \mathrm{GM}$ or $100 \mu \mathrm{M}$ bbG before cross-

Figure 1. Gangliosides inhibit cross-linking of GH-DAF in MDCK cells. MDCK GH-DAF cells were incubated with 0, 10, 50, and 100 $\mu \mathrm{M} \mathrm{GM} \mathrm{M}_{1}$ (A) or with 10,50 , and $100 \mu \mathrm{M}$ bbG (B) for $1 \mathrm{~h}$ at $37^{\circ} \mathrm{C}$. Cells were subsequently subjected to cross-linking with BS ${ }^{3}$. Proteins were resolved on 5-15\% SDS-PAGE and after Western blotting were detected with anti-GH antibody followed by ECL. Western blots were scanned, and the intensity of immunoreactive signal is given as relative optical density (ROD) for $0 \mu \mathrm{M} \mathrm{GM}_{1}$ (A, bottom curve), $0 \mu \mathrm{M} \mathrm{bbG}$ (B, bottom curve), $100 \mu \mathrm{M} \mathrm{GM}_{1}$ (A, top curve), and $100 \mu \mathrm{M}$ bbG (B, top curve). 


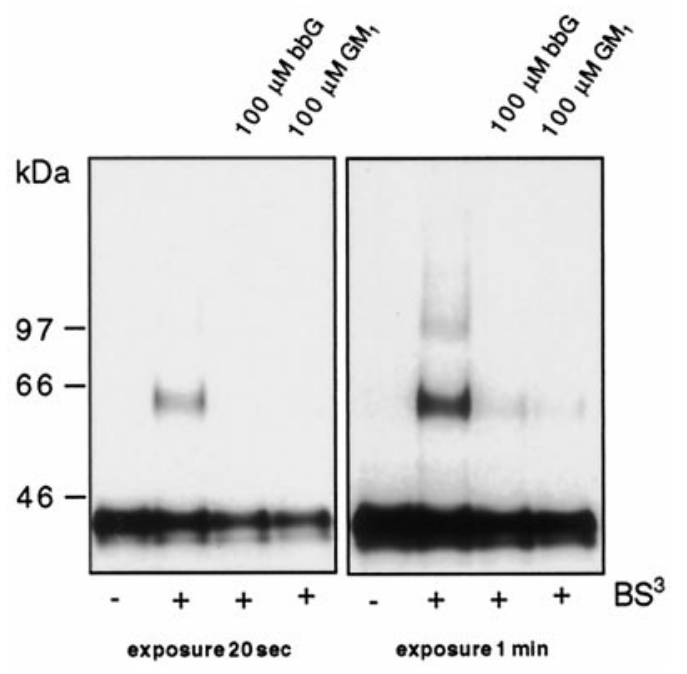

Figure 2. Gangliosides inhibit cross-linking of FR-GPI in CHO cells. CHO FR-GPI cells were incubated with $100 \mu \mathrm{M}$ bbG or with $100 \mu \mathrm{M} \mathrm{GM}_{1}$ for $1 \mathrm{~h}$ at $37^{\circ} \mathrm{C}$. Cells were subsequently subjected to cross-linking with $\mathrm{BS}^{3}$. Proteins were resolved on 5-15\% SDS-PAGE and after Western blotting were detected with antifolate receptor antibody followed by ECL.

linking, the cross-linking efficiency was reduced to $2.7 \pm 2.5$ and $3.3 \pm 2 \%$, respectively (Figure 2 ).

To quantify the amount of $\mathrm{GM}_{1}$ that is incorporated into the plasma membrane, we incubated MDCK GH-DAF cells with $1 \mu \mathrm{Ci} / \mathrm{ml}$ tritiated $\mathrm{GM}_{1}$ (final ganglioside concentration $100 \mu \mathrm{M}$ ) for $1 \mathrm{~h}$. Only $\sim 0.7 \%$ of exogenously added ganglioside associated with cells. Approximately $35 \%$ of total associated $\mathrm{GM}_{1}$ could be removed by incubating cells with
BSA solution (Figure 3A). By subsequent treatment of cells with trypsin, two pools of associated $\mathrm{GM}_{1}$ could be detected. Approximately $30 \%$ of the remaining $\mathrm{GM}_{1}$ was released by trypsin treatment (trypsin-labile pool), and 70\% was resistant (trypsin-stable pool) (Figure 3A). The trypsin-stable pool of $\mathrm{GM}_{1}$ likely corresponds to the molecules inserted into the plasma membrane, whereas the trypsin-labile pool is probably composed of ganglioside interacting with proteins protruding from the plasma membrane (Masserini et al., 1990; Saqr et al., 1993). The trypsin-stable pool of $\mathrm{GM}_{1}$ was shown to be enriched in the fraction resistant to extraction with Triton X-100 at $4^{\circ} \mathrm{C}$. After cells were incubated with $100 \mu \mathrm{M}$ tritiated $\mathrm{GM}_{1}, 3.74 \mathrm{nmol} \mathrm{GM}$ (per milligram protein) were found in the detergent-insoluble fraction, whereas $1.26 \mathrm{nmol} \mathrm{GM}_{1}$ were recovered from the soluble fraction, indicating that exogenous $\mathrm{GM}_{1}$ accumulates in rafts.

To rule out that inhibition of cross-linking of GH-DAF is due to the action of ganglioside loosely associated with the surface, cross-linking was performed on $\mathrm{GM}_{1}$-loaded cells, before and after incubation with BSA. The cross-linking efficiency remained the same under the two conditions ([Figure $3 \mathrm{~B}$ ] variation of efficiency was $<5 \%$ for all conditions). Hence, we conclude that gangliosides tightly associated with the membrane are responsible for this inhibition of cross-linking. Important was our finding that $70 \%$ of tightly associated GM1 was incorporated into the bilayer by the criterion used by previous authors (Kanda et al., 1982; Schwarzmann et al., 1983). We cannot completely rule out that the trypsin-labile pool contributes to inhibition of crosslinking, but this must be a minor effect, especially because the solubility of GH-DAF in TX-114 was significantly increased by gangliosides (see below). This latter finding is difficult to explain by ganglioside micelles bound to protruding proteins.
A

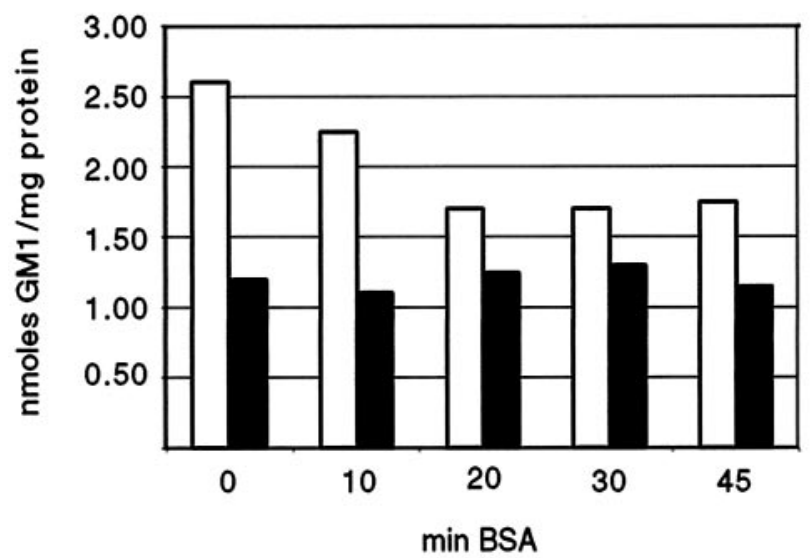

B

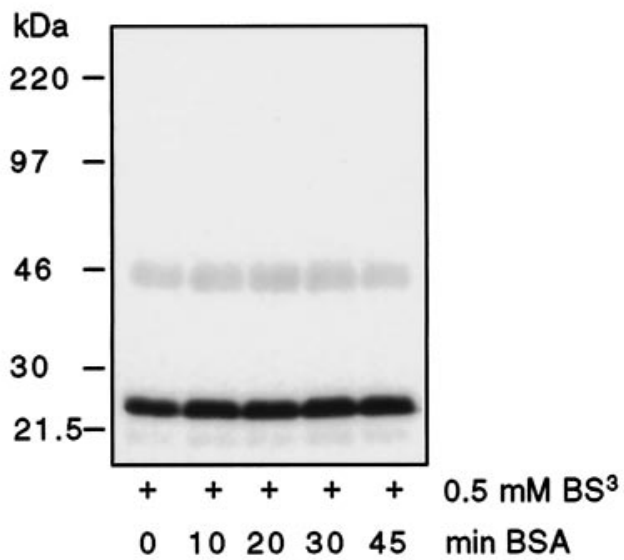

Figure 3. Incorporation of $\mathrm{GM}_{1}$ into the plasma membrane of MDCK GH-DAF cells. (A) MDCK GH-DAF cells were incubated with 1 $\mu \mathrm{Ci} / \mathrm{ml}$ tritiated $\mathrm{GM}_{1}$ (final ganglioside concentration $100 \mu \mathrm{M}$ ) for $1 \mathrm{~h}$ at $37^{\circ} \mathrm{C}$ and subsequently washed with BSA for 0 , 10 , 20, 30, or 45 min (open bars). The additive effect of trypsin treatment $\left(0.1 \%\right.$ trypsin for 5 min at $\left.37^{\circ} \mathrm{C}\right)$ after washing with BSA is shown as solid bars for each time point. (B) Cross-linking was performed after incubating GM 1 -loaded cells with BSA for 0, 10, 20, 30, or 45 min. SDS-PAGE, Western blotting, and detection were as described in Figure 1. 


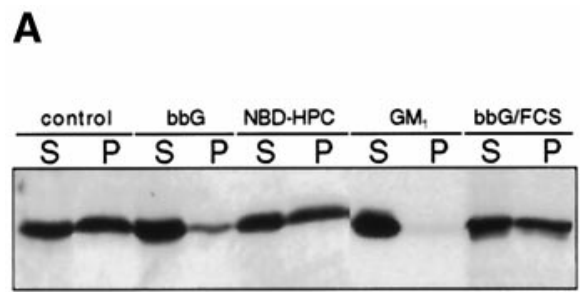

B

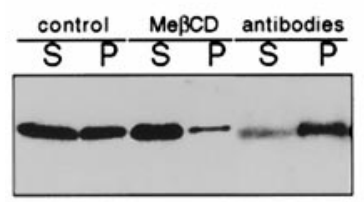

Figure 4. Gangliosides increase the detergent solubility of GHDAF. (A) MDCK GH-DAF cells were loaded with $100 \mu \mathrm{M}$ bbG for $1 \mathrm{~h}$ at $37^{\circ} \mathrm{C}$, with $100 \mu \mathrm{M}$ NBD-C ${ }_{6}-\mathrm{HPC}$ for $1 \mathrm{~h}$ at $8^{\circ} \mathrm{C}$, with $100 \mu \mathrm{M}$ $\mathrm{GM}_{1}$ for $1 \mathrm{~h}$ at $37^{\circ} \mathrm{C}$, or with $100 \mu \mathrm{M}$ bbG for $1 \mathrm{~h}$ followed by a $6-\mathrm{h}$ incubation period with serum containing DMEM (A) or treated with $10 \mathrm{mM}$ methyl- $\beta$-cyclodextrin for $1 \mathrm{~h}$ at $37^{\circ} \mathrm{C}$ or incubated with anti-GH for $1 \mathrm{~h}$ at $12^{\circ} \mathrm{C}$ followed by incubation with secondary antibody (B). Cells were extracted with Triton X-114 for $30 \mathrm{~min}$ at $4^{\circ} \mathrm{C}$ and subjected to centrifugation, and GH-DAF in the soluble (S) and insoluble fraction (I) was detected as described in MATERIALS AND METHODS.

\section{Gangliosides Change the Detergent Solubility of GH-DAF}

How do gangliosides inhibit cross-linking of GH-DAF? One possibility is that GPI-APs are excluded from rafts by gangliosides that are inserted into the lipid bilayer. An alternative explanation is that gangliosides bound to proteins protruding from the surface of the plasma membrane affect cross-linking by sterical hindrance. To distinguish between these two possibilities another experimental strategy was applied. An often used criterion for studying the association of a protein with rafts is its resistance to extraction with nonionic detergents such as Triton X-100 at $4^{\circ} \mathrm{C}$ (Brown and Rose, 1992). This prompted us to investigate the detergent solubility of GH-DAF after ganglioside loading of cells. We found that solubility of GH-DAF in TX-114 was significantly increased from $51 \pm 4$ to $83 \pm 10$ and $76 \pm 8 \%$ in $\mathrm{GM}_{1}$ - and bbG-loaded cells, respectively (Figure 4A).

It is known that depletion of cholesterol from cellular membranes increases the solubility of GPI-APs in nonionic detergent (Cerneus et al., 1993; Hanada et al., 1995; Scheiffele et al., 1997). Confirming earlier reports, the solubility of GH-DAF on TX-114 extraction was shifted to $80 \pm 7 \%$ after extraction of membrane cholesterol with CD (Figure 4B). In contrast, stabilization of rafts by antibody-induced crosslinking decreases the solubility of GH-DAF to $34 \pm 7 \%$ (Figure 4B).

These results indicate that manipulating the lipid content of cellular membrane by application of exogenous gangliosides modulates both the clustering behavior of GPI-APs

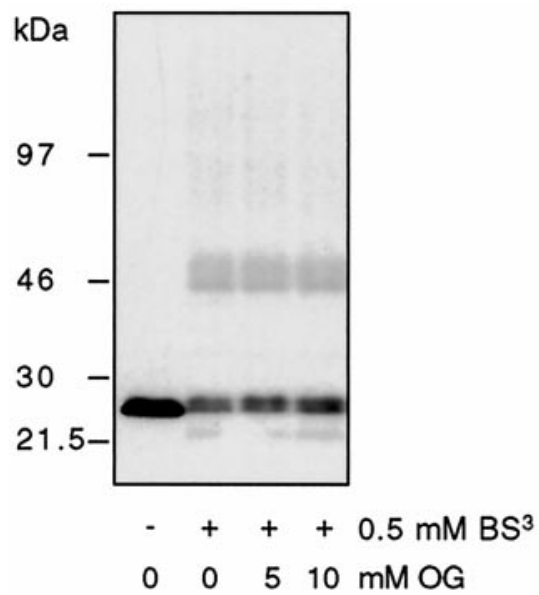

Figure 5. The effect of octylglucoside on rafts is different from that of gangliosides. MDCK GH-DAF cells were incubated for $1 \mathrm{~h}$ with 5 and $10 \mathrm{mM}$ octylglucoside and subjected to cross-linking with $\mathrm{BS}^{3}$. A slight decrease of cross-linking was observed only with $10 \mathrm{mM}$ OG. For all concentrations tested, membranes remained intact (see RESULTS).

and the solubilization in TX-114 at $4^{\circ} \mathrm{C}$. Taking together the data from the chemical cross-linking and detergent-extraction approach, we suggest that gangliosides inserted into the plasma membrane displace GPI-APs from lipid microdomains.

\section{Effect of Gangliosides on Rafts Is Not Due to Solubilization of the Membrane}

We have shown that loading of MDCK GH-DAF cells with gangliosides displaces GPI-APs from rafts. To rule out the possibility that these effects are partly due to detergent-like properties of gangliosides, we used $n$-octyl- $\beta$-D-glucopyranoside (OG). This detergent chemically resembles gangliosides (i.e., containing carbohydrate head group) and is known to fully solubilize GPI-APs when used above the critical micellar concentration (20-25 mM). MDCK GH-DAF cells were incubated with different concentrations of OG and subjected to cross-linking with $\mathrm{BS}^{3}$. Using the same concentrations of OG as used for gangliosides (10-100 $\mu \mathrm{M})$, no effect on cross-linking of GH-DAF was observed. Even when cells were incubated with a 100-fold higher concentration of OG (10 mM), only a slight inhibition of cross-linking was observed ([Figure 5] inhibition was $3.5 \pm 0.7 \%$ ). Remarkably, even under this condition membranes remained intact, because caveolin-1, a membrane protein having both $\mathrm{N}$ and $\mathrm{C}$ termini exposed to cytoplasm, was not cross-linked. Caveolin-1 was found as a high molecular weight cross-linked product only when OG was applied above its critical micellar concentration $(20 \mathrm{mM})$. Treatment of MDCK GH-DAF cells with $100 \mu \mathrm{M} \mathrm{GM}$ did not lead to cross-linking of caveolin-1. Taken together, these data show that the inhibition of GH-DAF cross-linking by gangliosides is not due to solubilization of the membrane by detergent-like properties of gangliosides. 
A

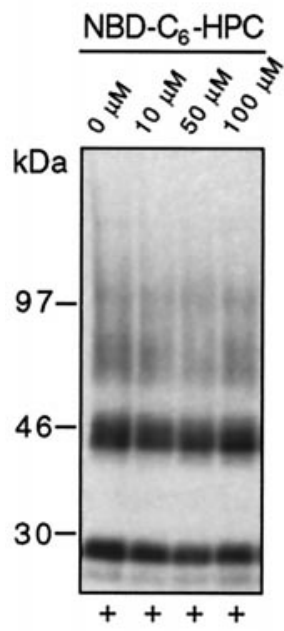

B

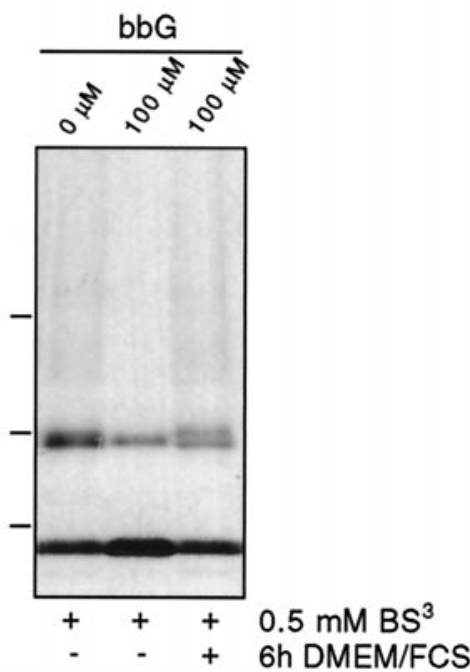

Figure 6. The inhibition of cross-linking of GH-DAF is a specific property of gangliosides. (A) MDCK GH-DAF cells were incubated with $0,10,50$, or $100 \mu \mathrm{M}$ NBD-C ${ }_{6}-\mathrm{HPC}$ for $30 \mathrm{~min}$ at $8^{\circ} \mathrm{C}$ before being subjected to cross-linking with $\mathrm{BS}^{3}$. SDS-PAGE, Western blotting, and detection were as described in Figure 1. (B) MDCK GHDAF cells were incubated with 0 or $100 \mu \mathrm{M}$ bbG for $1 \mathrm{~h}$ followed by a 6-h incubation with serum-containing medium as indicated in the figure. Cells were subjected to cross-linking followed by SDS-PAGE, Western blotting, and detection as detailed in Figure 1.

\section{Inhibition of GH-DAF Cross-linking with Gangliosides Is Specific and Reversible}

We tested whether the clustering of GPI-anchored proteins is a specific property of gangliosides. A lipid expected not to be a constituent of rafts should have no effect on crosslinking and solubility of GH-DAF. Optimally, phosphatidylcholine molecules such as those found in cell membranes should be used for this control; however, these lipids cannot be introduced into the membrane by exogenous addition. We therefore used a partially water-soluble fluorescently labeled analogue of phosphatidylcholine (NBD-C $-\mathrm{HPC})$. It is known that NBD-C ${ }_{6}$-lipids are rapidly transferred to the plasma membrane at low temperature, and their accumulation in the plasma membrane is easily monitored by immunofluorescence microscopy (Kok and Hoekstra, 1993). We have tested the detergent insolubility of NBD- $\mathrm{C}_{6}-\mathrm{HPC}$. Cells were loaded with NBD- $\mathrm{C}_{6}-\mathrm{HPC}$, and detergent extraction was performed at $4^{\circ} \mathrm{C}$ with Triton $\mathrm{X}-114$. More than $99 \%$ of NBD- $\mathrm{C}_{6}$-HPC was recovered from the detergent-soluble fraction, indicating that the lipid does not associate with rafts. As expected, no change in the cross-linking pattern was detected on incubation with various concentrations of NBD-C 6 - HPC (cross-linking efficiency was $73 \pm 5 \%$ in cells treated with $100 \mu \mathrm{M}$ NBD-C 6 -HPC as compared with $73 \pm$ $6 \%$ in control cells) (Figure 6A). Also, solubility of GH-DAF (54 $\pm 2 \%$ soluble) was not changed by NBD-C 6 -HPC (Figure $4 \mathrm{~A})$.
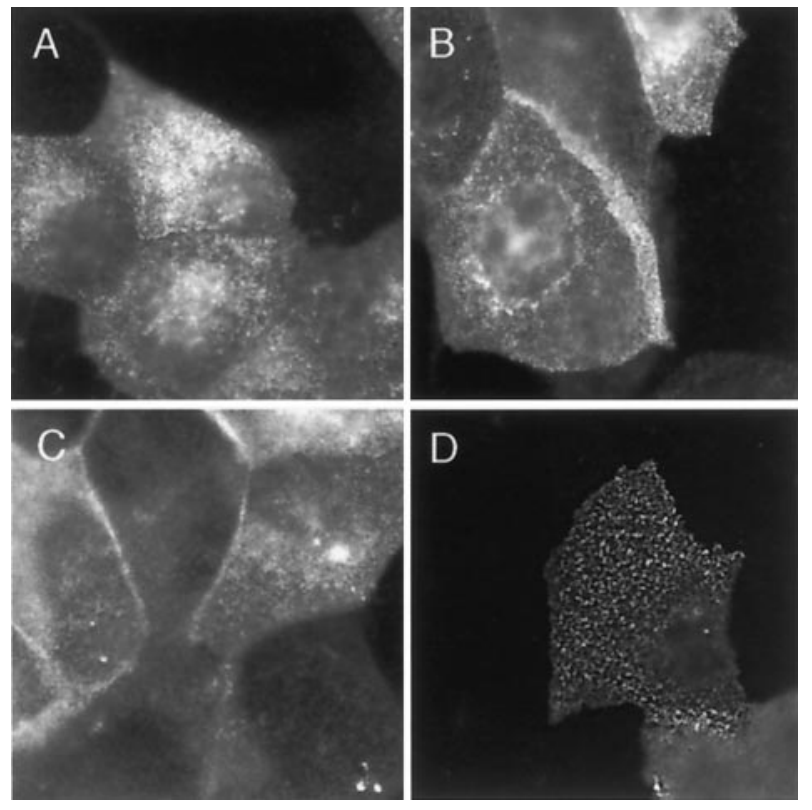

Figure 7. Ganglioside treatment does not change the immunofluorescence pattern of GH-DAF. MDCK GH-DAF cells were incubated without any additions (A and D), with $100 \mu \mathrm{M}$ bbG (B), and with $10 \mathrm{mM} \mathrm{CD} \mathrm{(C)} \mathrm{for} 1 \mathrm{~h}$ at $37^{\circ} \mathrm{C}$, respectively. Cells were fixed and labeled with anti-GH antibody followed by Cy3-conjugated anti-sheep IgG (A-C) or subjected to antibody-induced cross-linking before fixation (D) as described in MATERIALS AND METHODS.

To determine whether inhibition of GH-DAF cross-linking by gangliosides is reversible, MDCK GH-DAF cells were loaded with $100 \mu \mathrm{M} \mathrm{bbG}$ and subsequently incubated for $6 \mathrm{~h}$ in serum-containing medium before cross-linking. As shown in Figure $6 \mathrm{~B}, 6 \mathrm{~h}$ of incubation with serum-containing medium were sufficient to almost fully restore the crosslinking pattern of GH-DAF (cross-linking efficiency was $6 \pm$ $1 \%$ lower than control cells).

The detergent insolubility of GH-DAF in TX-114 was also restored by incubation of bbG-loaded cells with serum-containing medium for $6 \mathrm{~h}(61 \pm 4 \%$ soluble) (Figure $4 \mathrm{~A})$.

\section{Inhibition of Copatching of Influenza HA and GH- DAF by Gangliosides}

Rafts are thought to be small and highly dynamic structures, which explains why they cannot be resolved by conventional microscopical techniques. We wanted to test whether loading of cells with gangliosides leads to a redistribution of GPI-APs. The distribution of GH-DAF on MDCK cells with or without bbG loading was analyzed by immunofluorescence labeling. To avoid postfixational redistribution of GHDAF we used formaldehyde fixation combined with subsequent methanol fixation (Harder et al., 1998). Incubation of cells with $100 \mu \mathrm{M}$ bbG for $1 \mathrm{~h}$ before fixation and antibody labeling had no effect on the diffuse distribution of GH-DAF on the cell surface (Figure 7, A and B). The intracellular staining is derived from Golgi and/or endosomal localization of the pro- 

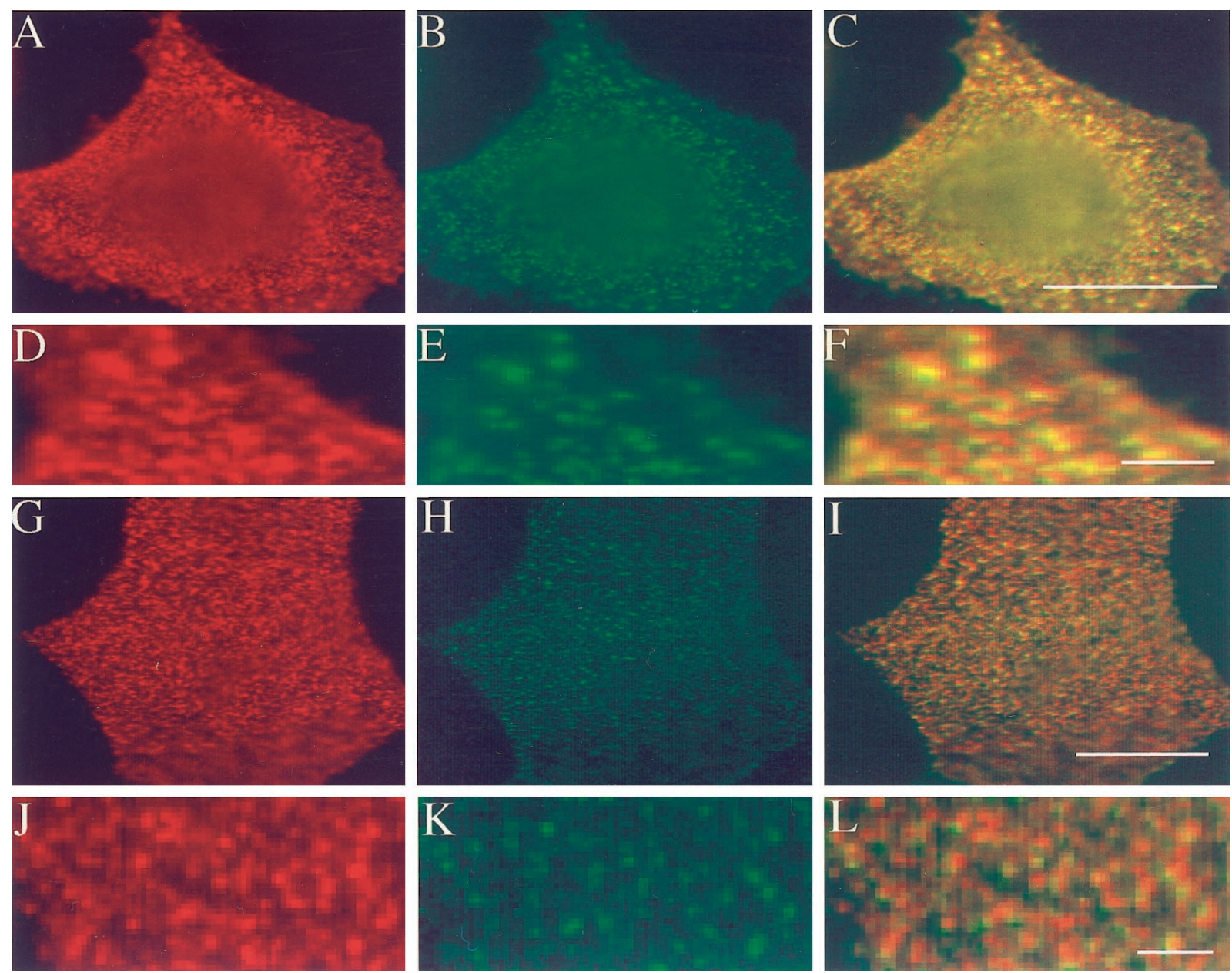

Figure 8. Inhibition of copatching of influenza HA and GH-DAF by gangliosides. MDCK GH-DAF cells were infected with influenza HA virus and then incubated with DMEM (A-F) or $100 \mu \mathrm{M} \mathrm{GM}_{1}$ in DMEM (G-L) for $1 \mathrm{~h}$ at $37^{\circ} \mathrm{C}$. After subsequent treatment with a mixture of monoclonal anti-HA and sheep polyclonal anti-GH antibodies at $4^{\circ} \mathrm{C}$, patching was detected using Cy-3-anti-sheep-labeled (red) and FITC-anti-mouse-labeled (green) secondary antibodies. Panels in the left column show distribution of GH, panels in the middle column show distribution of HA, and panels in the right column show the merge of both signals. D-F display a detail of A-C correspondingly, whereas J-L display that of G-I. Bars: F, L, $2 \mu \mathrm{m}$; C, I, $8 \mu \mathrm{m}$.

tein. Depletion of membrane cholesterol with $10 \mathrm{mM} \mathrm{CD}$ also did not lead to detectable changes in the distribution of GHDAF (Figure 7C). In comparison, addition of antibodies to GH-DAF before fixation led to a patched distribution of the immunofluorescence signal (Figure 7D).

Recently, it was shown that incubating living cells simultaneously with antibodies against raft-associated proteins leads to redistribution of the independently cross-linked components into overlapping patches (Harder et al. 1998). Copatching was only observed for pairs of raft markers but not for pairs of raft/non-raft marker, suggesting attractive forces in the common lipid environment of raft proteins (Harder et al. 1998).

We used the same approach to investigate whether exogenous application of gangliosides disturbs the physical connection of GH-DAF to lipid microdomains. As a raft-associated protein marker we expressed the trimeric transmembrane protein influenza HA in MDCK GH-DAF cells.

Cells were incubated simultaneously with monoclonal anti-HA and polyclonal anti-GH antibodies at $4^{\circ} \mathrm{C}$, followed by incubation with the respective secondary antibodies. Microscopical analysis showed copatching of HA and GH-DAF in the majority of cells (60\% copatching, 35\% partial overlap, and 5\% random distribution), confirming the previous report by Harder et al. (1998) (Figure 8, A-F). When cells were incubated for $1 \mathrm{~h}$ with $100 \mu \mathrm{M} \mathrm{GM}_{1}$ before antibody-induced cross-linking, in most cells only partial coclustering of $\mathrm{HA}$ and GH-DAF was observed (31\% coclustering, 50\% partial overlap, and 19\% random distribution) (Figure 8, G-L). This result shows that attractive forces between patches of HA and GH-DAF are disturbed by application of gangliosides and strengthens 
our conclusion that GPI-APs are displaced from lipid microdomains.

\section{DISCUSSION}

The aim of this study was to investigate how application of gangliosides affects cholesterol-sphingolipid microdomains. Previously, using a chemical cross-linking approach, we have demonstrated that GPI-anchored proteins reside in clusters on the surface of living cells (Friedrichson and Kurzchalia, 1998). Here we show that gangliosides inhibit crosslinking of GPI-anchored proteins and moreover increase their detergent solubility.

How do gangliosides exert these effects? The inhibitory effect of gangliosides on cross-linking could be explained in two ways. Firstly, because of the characteristic property of sphingolipids (gangliosides) to self-aggregate, they could enlarge existing rafts and therefore "dilute" GH-DAF molecules within them. The resulting increase of the distance between neighboring GH-DAF molecules could then interfere with cross-linking. Secondly, it is possible that application of gangliosides displaces GPI-anchored proteins from rafts by disrupting attractive forces between the GPI anchor and surrounding lipids. The GPI-anchored proteins thereby would be deprived of their lipid environment and could escape from rafts. A similar destabilization or disassembly of rafts would occur if gangliosides that do not associate with GPI-AP-containing rafts sequester essential raft lipids, such as cholesterol.

One way to distinguish between the possibilities raised above is to analyze whether addition of exogenous gangliosides leads to changes in the detergent solubility of GHDAF. It is known that GPI-anchored proteins are to a great extent insoluble in nonionic detergents (Brown and Rose, 1992). A primary requirement for detergent insolubility in vitro is the presence of optimal concentrations of cholesterol, glycosphingolipids, and saturated acyl-chain-containing phospholipids (Schroeder et al., 1998). Accordingly, depleting cells of cholesterol has been shown to increase detergent solubility of GPI-APs (Cerneus et al., 1993; Hanada et al., 1995); however, in the case of gangliosides the opposite is true: loading cells with gangliosides renders GH-DAF detergent soluble. This finding is somewhat unexpected, because increasing the concentration of a raft lipid would be thought to result in raft stabilization. The fact that gangliosides interfere with cross-linking and increase detergent solubility of GH-DAF suggests that they act in a raft-disrupting manner, possibly driving GPI-APs partially out of rafts. This view is supported by the finding that gangliosides disturb the copatching of HA and GH-DAF. Copatching of two raft components is most likely a consequence of the coalescence of a common lipid microdomain.

What are the forces keeping rafts together? Lipid-lipid interactions within rafts are poorly understood. Attractive forces between the GPI-anchor and raft lipids have been inferred from in vitro studies (Schroeder et al., 1994). Interestingly, although GPI-anchored proteins are partially insoluble in most nonionic detergents, octylglucoside completely solubilizes GPI-anchored proteins (Brown and Rose, 1992). This detergent has a polar carbohydrate head group resembling naturally occurring glycolipids that might be involved in disrupting the at- tractive forces within sphingolipid-cholesterol rafts. The finding of the lectin VIP36 in detergent-insoluble cell extracts led to the proposal that carbohydrate interactions are involved in raft recruitment of proteins (Fiedler et al., 1994). We cross-linked GH-DAF in the presence of structural carbohydrates of the GPI-anchor, but no change in the cross-linking pattern was detected (our unpublished results). This finding does not support a role for carbohydrate interactions in raft assembly. Recently it was demonstrated that rafts are stabilized by antibody-induced cross-linking of a raft protein, which led to enhanced resistance to Triton extraction (Harder et al., 1998).

The findings presented in this article might link effects of exogenously added gangliosides on signaling pathways to raft function (Hakomori and Igarashi, 1995). GPIanchored proteins were reported to associate with tyrosine kinases of the src family (Brown, 1992). In addition, caveolae, plasma membrane invaginations where cell signaling proteins are concentrated, are involved in sequestering and organizing raft lipid domains. Many signal transduction molecules, which are all modulated by gangliosides, are found to be associated with sphingolipidcholesterol rafts or caveolae. PDGF, EGF, protein kinase $\mathrm{C}$, and the insulin receptor have been reported to localize to caveolae (Liu et al., 1996; Couet et al., 1997; Liu et al., 1997; Wu et al., 1997). At the same time, signal transduction pathways mediated by these molecules are inhibited by the exogenous addition of gangliosides (Bremer et al., 1984; Bremer et al., 1986; Hannun and Bell, 1987). Therefore, agents causing clustering or unclustering of GPI-APcontaining microdomains might be important tools for modulating these signal transduction pathways. For example, antibody-induced patching of GPI-anchored placental alkaline phosphatase leads to accumulation of the src-like tyrosine kinase fyn (Harder et al., 1998). Physiological responses induced by raft-clustering have been described in lymphocytes (Brown, 1993). For example, antibody-induced cross-linking of GPI-anchored proteins leads to activation of T lymphocytes (Thomas and Samelson, 1992), and cross-linking of the IgE receptor Fc $\in$ RI mediates an allergic response, including secretion of histamine in mast cells (Holowka and Baird, 1996; Field et al., 1997). Hence, many cellular signal-transduction events might depend on the assembly of raft lipid and protein components. Disassembly of rafts by exogenous application of gangliosides could possibly antagonize raft-dependent signal transduction. Tumor cells might exploit this mechanism to escape immune response. It is well known that gangliosides, which are shed by tumor cells, inhibit T cell activation, which is a raft-mediated process ( $\mathrm{Lu}$ and Sharom, 1996; Lanzavecchia A. et al. 1999). Interestingly, we detected an increase of autophosphorylation of several protein kinases on addition of ganglioside to cells (our unpublished observation).

In addition, gangliosides might be useful agents for studying the pathogenesis of human diseases, which have been linked to rafts. We have recently shown that cholesterol depletion of hippocampal neurons inhibits secretion of $\beta$-amyloid peptide, suggesting that rafts may play a role in the proteolytic processing of the amyloid precursor protein of Alzheimer's disease (Simons et al., 1998). Transformation of the GPI-anchored prion protein to the 
Scrapie protein isoform has also been associated with the cholesterol-sphingolipid microdomains Taraboulos et al., 1995). It will be interesting to see whether gangliosides influence the processing of the amyloid precursor protein or the prion protein.

\section{ACKNOWLEDGMENTS}

We thank Dr. Satyajit Mayor (National Centre for Biological Sciences, Bangalore, India) and Sushmita Mukherjee (Weill Medical College of Cornell University, New York, NY) for the critical reading of this manuscript. The work was supported by grants from the Deutsche Forschungsgemeinschaft (Ku 945/1-3), the Human Frontier Science Program, and the German-Israeli Foundation.

\section{REFERENCES}

Bremer, E.G., Hakomori, S., Bowen-Pope, D.F., Raines, E.W., and Ross, R. (1984). Ganglioside-mediated modulation of cell growth, growth factor binding, and receptor phosphorylation. J. Biol. Chem. $259,6818-6825$

Bremer, E.G., Schlessinger, J., and Hakomori, S. (1986). Gangliosidemediated modulation of cell growth: specific effects of $\mathrm{GM}_{3}$ on tyrosine phosphorylation of the epidermal growth factor receptor. J. Biol. Chem. 261, 2434-2440.

Brown, D. (1993). The tyrosine kinase connection: how GPI-anchored proteins activate T cells. Curr. Opin. Immunol. 5, 349-354.

Brown, D.A. (1992). Interactions between GPI-anchored proteins and membrane lipids. Trends Cell Biol. 2, 338-343.

Brown, D.A., and Rose, J.K. (1992). Sorting of GPI-anchored proteins to glycolipid-enriched membrane subdomains during transport to the apical cell surface. Cell 68, 533-544.

Cerneus, D.P., Ueffing, E., Posthuma, G., Strous, G.J.,. and van der Ende, A. (1993). Detergent insolubility of alkaline phosphatase during biosynthetic transport and endocytosis: role of cholesterol. J. Biol. Chem. 268, 3150-3155.

Couet, J., Saragiacomo, M., and Lisanti, M.P. (1997). Interaction of a receptor tyrosine kinase, EGF-R, with caveolins. Caveolin binding regulates tyrosine and serine/threonine kinase activities. J. Biol. Chem. 272, 30429-30438.

Fiedler, K., Kobayashi, T., Kurzchalia, T.V., and Simons, K. (1993). Glycosphingolipid-enriched, detergent-insoluble complexes in protein sorting in epithelial cells. Biochemistry 32, 6365-6373.

Fiedler, K., Parton, R.G., Kellner, R., Etzold, T., and Simons, K. (1994). VIP36, a novel component of glycolipid rafts and exocytic carrier vesicles in epithelial cells. EMBO J. 13, 1729-1740.

Field, K.A., Holowka, D., and Baird, B. (1997). Compartmentalized activation of the high affinity immunoglobulin $\mathrm{E}$ receptor within membrane domains. J. Biol. Chem. 272, 4276-4280.

Friedrichson, T., and Kurzchalia, T.V. (1998). Microdomains of GPIanchored proteins in living cells revealed by chemical cross-linking. Nature 394, 802-805.

Geisler, F.H., Dorsey, F.C., and Coleman, W.P. (1991). Recovery of motor function after spinal-cord injury: a randomized, placebocontrolled trial with GM-1 ganglioside. New Engl. J. Med. 324, $1829-1838$

Hadjiconstantinou, M., and Neff, N.H. (1998). GM1 ganglioside: in vivo and in vitro trophic actions on central neurotransmitter systems. J. Neurochem. 70, 1335-1345.
Hakomori, S., and Igarashi, Y. (1995). Functional role of glycosphingolipids in cell recognition and signaling. J. Biochem. 118, 10911103.

Hanada, K., Nishijima, M., Akamatsu, Y., and Pagano, R.E. (1995). Both sphingolipids and cholesterol participate in the detergent insolubility of alkaline phosphatase, a glycosylphosphatidylinositolanchored protein, in mammalian membranes. J. Biol. Chem. 270, $6254-6260$.

Hannun, Y.A., and Bell, R.M. (1987). Lysosphingolipids inhibit protein kinase C: implications for the sphingolipidoses. Science 235, 670-674.

Harder, T., Scheiffele, P., Verkade, P., and Simons, K. (1998). Lipid domain structure of the plasma membrane revealed by patching of membrane components. J. Cell Biol. 141, 929-942.

Holowka, D., and Baird, B. (1996). Antigen-mediated IgE receptor aggregation and signaling: a window on cell surface structure and dynamics. Annu. Rev. Biophys. Biomol. Struct. 25, 73-80.

Kanda, S., Inoue, K., Nojima, S., Utsumi, H., and Wiegandt, H. (1982). Incorporation of spin-labeled ganglioside analogues into cell and liposomal membranes. J. Biochem. (Tokyo) 91, 1707-1718.

Kharlamov, A., Zivkovic, I., Polo, A., Armstrong, D.M., Costa, E., and Guidotti, A. (1994). LIGA20, a lyso derivative of ganglioside GM1, given orally after cortical thrombosis reduces infarct size and associated cognition deficit. Proc. Natl. Acad. Sci. USA 91, 63036307.

Kok, J.W., and Hoekstra, D. (1993). Fluorescent and Luminescent Probes for Biological Activity, New York: Academic Press.

Lanzavecchia, A., Lezzi, G., and Viola A. (1999). From TCR engagement to T cell activation: a kinetic view of T cell behavior. Cell 96, 1-4.

Lenzi, G.L., et al. (1994). Early treatment of stroke with monosialoganglioside GM1. Efficiency and safety results of the early stroke trial. Stroke 25, 1552-1558.

Liu, J., Oh, P., Horner, T., Rogers, R.A., and Schnitzer, J.E. (1997). Organized endothelial cell surface signal transduction in caveolae distinct from glycosylphosphatidylinositol-anchored protein microdomains. J. Biol. Chem. 272, 7211-7222.

Liu, P., Ying, Y., Ko, Y.G., and Anderson, R.G. (1996). Localization of platelet-derived growth factor-stimulated phosphorylation cascade to caveolae. J. Biol. Chem. 1996, 10299-10303.

Lu, P., and Sharom, F.J. (1996). Immunosuppression by YAC-1 lymphoma: role of shed gangliosides. Cell Immunol. 173, 22-32.

Masserini, M., Giuliani, A., Palestini, P., Acquotti, D., Pitto, M., Chigorno, V., and Tettamanti, G. (1990). Association to HeLa cells and surface behavior of exogenous gangliosides studied with a fluorescent derivative of GM1. Biochemistry 29, 697-701.

Saqr, H.E., Pearl, D.K., and Yates, A.J. (1993). A review and predictive models of ganglioside uptake by biological membranes. J. Neurochem. 61, 395-411.

Scheiffele, P., Roth, M.G., and Simons, K. (1997). Interaction of influenza virus hemagglutinin with sphingolipid-cholesterol membrane domains via its transmembrane domain. EMBO J. 16, 55015508 .

Schneider, J.S., Pope, A., Simpson, K., Taggart, J., Smith, M.G., and DiStefano, L. (1992). Recovery from experimental parkinsonism in primates with GM1 ganglioside treatment. Science 256, 843-846.

Schroeder, R., London, E., and Brown, D. (1994). Interactions between saturated acyl chains confer detergent resistance to lipids and glycosylphosphatidylinositol (GPI)-anchored proteins: GPI-anchored proteins in liposomes and cells show similar behavior. Proc. Natl. Acad. Sci. USA 91, 12130-12134.

Schroeder, R.J., Ahmed, S.N., Zhu, Y., London, E., and Brown, D.A. (1998). Cholesterol and sphingolipid enhance the Triton X-100 in- 
solubility of glycosylphosphatidylinositol-anchored proteins by promoting the formation of detergent-insoluble ordered membrane domains. J. Biol. Chem. 273, 1150-1157.

Schwarzmann, G., Hoffmann Bleihauer, P., Schubert, J., Sandhoff, K., and Marsh, D. (1983). Incorporation of ganglioside analogues into fibroblast cell membranes. A spin-label study. Biochemistry 22, 5041-5048.

Simons, K., and Ikonen, E. (1997). Functional rafts in cell membranes. Nature 387, 569-572.

Simons, M., Keller, P., DeStrooper, B., Beyreuther, K., Dotti, C.G., and Simons, K. (1998). Cholesterol depletion inhibits generation of $\beta$-amyloid peptide in hippocampal neurons. Proc. Natl. Acad. Sci. USA 95, 6460-6464.

Sonnino, S., Ghidoni, R., Gazzotti, G., Kirschner, G., Galli, G., and Tettamanti, G. (1984). High performance liquid chromatography preparation of the molecular species of GM1 and GD1a gangliosides with homogeneous long chain base composition. J. Lipid Res. 25, 620-629.
Taraboulos, A., Scott, M., Semenow, A., Avraham, D., Laszlo, L., and Prusiner, S.B. (1995). Cholesterol depletion and modification of $\mathrm{COOH}$-terminal targeting sequence of the prion protein inhibit formation of the scrapie isoform. J. Cell Biol. 129, 121-132.

Tettamanti, G., Bonali, F., Marchesini, S., and Zambotti, V. (1973). A new procedure for the extraction, purification and fractionation of brain gangliosides. Biochim. Biophys. Acta 296, 160-170.

Thomas, P.M., and Samelson, L.E. (1992). The glycophosphatidylinositol-anchored thy-1 molecule interacts with the p60fyn protein tyrosine kinase in T cells. J. Biol. Chem. 267, 12317-12322.

Varma, R., and Mayor, S. (1998). GPI-anchored proteins are organized in submicron domains at the cell surface. Nature 394, $798-802$.

Wu, C., Butz, S., Ying, Y., and Anderson, R.G. (1997). Tyrosine kinase receptors concentrated in caveolae-like domains from neuronal plasma membrane. J. Biol. Chem. 272, 3554-3559. 